\title{
Slavery, capitalism, incorporation and the Close Harbour Company of Jamaica, circa 1800
}

Levels of incorporation of joint-stock companies were far lower between 1790 and 1860 than in the American South, let alone New England and the British Isles, suggesting that slavery had a direct and proportional impact on patterns of incorporation and wider economic development. Examining the foundation of the Close Harbour Company of Jamaica between 1795 and 1803, the first joint-stock company chartered by a colonial legislature in the British West Indies, shows that potential entrepreneurs did not face legal or political obstacles, but rather a range of exogenous and endogenous economic factors arising in part from the conditions of a slave society which discouraged company formation. The effect may have been to exacerbate existing levels of economic backwardness in these islands by cutting off the supplies of capital needed for modernisation, thereby contributing to their underdevelopment.

Keywords: Caribbean; slavery; capitalism; corporations; infrastructure 
In August 1802 several hundred workmen in east London put the finishing touches to the first section of the West India Docks, a huge complex of docks, basins, wharfs and warehouses that would eventually cover more than one hundred acres in the Pool of London. Intended to handle the hundreds of thousands of tons of sugar, rum, cotton and coffee arriving from the West Indies, it was an important statement of confidence by the merchants of London in the long-term future of the 'triangular trade' in enslaved people and sugar, even though the slave trade would be abolished only five years later. At around the same time but on the other side of the Atlantic, the finishing touches were likewise being put to a new 'close' or enclosed harbour at the town of Montego Bay on the north-western side of Jamaica. As in Britain the island was struggling to cope with an immense upsurge in imports and exports, and so a jointstock company was incorporated by the assembly in 1795 to build a harbour of refuge that would protect shipping in the worst winter storms and help relieve pressure on one of Jamaica's main ports. It was the first joint-stock company incorporated by a colonial government in the British West Indies itself, rather than in Britain, and was an equally important - and equally mistaken - statement of confidence by the planters and merchants of Jamaica in the future of the island. Although it enjoyed only limited commercial success, its history offers a broader perspective on the linked themes of slavery, capitalism and incorporation in Britain and the United States during the first industrial revolution. Lower numbers of joint-stock companies were chartered in the American South compared to the northern states between 1790 and 1860, and it has been suggested that this was a cause or consequence, or possibly both, of the negative economic externalities caused by their reliance on slavery. A study of the Close Harbour Company and incorporation in the British West Indies in the same period shows that it had far higher levels of slavery and far lower levels of incorporation, for 
social and economic rather than political reasons, demonstrating how the interaction of slavery and capitalism was a complex process which could undermine as well as encourage the industrialisation described by recent studies of 'slavery's capitalism'.

Among the many factors underlying the industrial revolutions of Britain and North America between 1750 and 1850 was the rise of new corporate forms, in particular the joint-stock company or corporation. By bringing together both large and small investors the company made it possible to raise and use greater amounts of capital in ventures that were beyond the means of smaller entrepreneurs or partnerships. It also offered a stable legal framework that allowed for the cultivation of technical and then eventually managerial expertise. Admittedly the corollary was the economic damage caused by rent-seeking, especially where powerful companies such as the East India Company or the Royal African Company managed to secure or assert monopolistic powers over a segment of the economy (Jones and Ville 1996; Erikson and Bearman 2006;

). An established body of work has argued though that, on balance, greater incorporation was closely linked with the growth of industrial capitalism within the British Isles and North America (Scott, 1951; Dubois, 1938; Hunt, 1969; Davis, 1965; Abbott, 1936). Most recently, Robert Wright has made a forceful argument for its importance in the United States (Wright, 2014). 'Corporate precocity helped the early United States economy to grow and develop more rapidly than any other in the world', he argues, '... [as] corporations were not merely a convenient means of 
improving economic efficiency and living standards; they were often indispensable to those lofty goals because they provided unique ways for people to cooperate' (Wright, 2016, pp. 7-8). High levels of incorporation therefore supported and promoted economic development, by enabling larger and more secure accumulations and applications of capital and expertise.

This can be seen clearly in how the growth in joint-stock companies and chartered corporations led to a vastly increased investment in this period in infrastructure, such as roads, canals and railways, which eventually created 'transportation revolutions' that paralleled or in some cases even preceded the industrial revolutions (Taylor, 1951, pp. 104-48; Freeman, 1983; Bogart, 2014). Freight rates in shipping began to fall, driven by new technologies, economies of scale and better management, but also improved port and harbour infrastructure (Armstrong and Bagwell, 1983; Jackson, 1983; Jackson, 2001). In 1700 there were only ten acres of wet docks in Britain but this had increased to eighty acres by 1800 and four hundred by 1830 , led mainly by chartered corporations (Swann, 1960; Kenwood, 1971). The West India Docks Company noted above, for instance, raised over a million pounds for building the new docks in London, while Bristol and Liverpool set up corporations in this period which spent $£ 600,000$ apiece on new harbours (Broadbank, 1921; Stern, 1952; Draper, 2008; Nelson, 2016, pp. 235-67; Williams, 1962). On a rather smaller scale, the town of Kingston-on-Hull secured a municipal corporation which spent $£ 73,000$ between 1774 and 1778 on new docks, relieving a major bottleneck for shipping in north-eastern England (Swann, 1960, pp. 38-9; Jackson, 1972, pp. 234-71). Corporations were likewise fundamental to the growth of public infrastructure in the United States during the period of 'internal improvement' between 1790 and 1860, which far exceeded the 
modest legacies of colonial rule (Bridenbaugh, 1971b, pp. 22-4, 170-4, 325-8;

Bridenbaugh, 1971a, pp. 38-41, 245-7; Taylor, 1951, pp. 15-55; Larson, 2001). Incorporations rose sharply after independence in 1783 and were concentrated in the construction of turnpikes, canals and railways that opened up the continental interior (Davis, 1965, vol. i, 87-93, vol. ii, 186-227, 247-54; Seavoy, 1982, pp. 39-51). Incorporation enabled encouraged transportation improvements that facilitated further economic growth, leading to a mutually-reinforcing spiral of improvement.

It is consequently unsurprising that studies by Richard Sylla and Robert Wright have shown that the United States and Britain, as the leading industrial nations of the nineteenth century, enjoyed far higher levels of incorporation, by number and by total capital respectively, than France or Prussia, even allowing for the numerous cultural and legal differences pointed out by Les Hannah (Sylla and Wright, 2013; Hannah, 2014). Sylla and Wright have also identified regional differences in incorporation within the United States between 1790 and 1860 which map onto, to some extent, regional variations in industrial development and complicate any simple relationship between slavery and capitalism. On the one hand, at least 7,394 corporations were chartered by legislatures in the southern states during this period, when slavery dominated their society and economy, compared to the 478 corporations chartered within the undeveloped western frontier states. 'Hoary claims that southerners were by nature reluctant entrepreneurs and incompetent managers no longer make sense, except perhaps in comparison to their somewhat more advanced northern neighbours', Wright concludes, implying that slavery and modern industrial development were compatible (Wright, 2014, p. 204; Wright, 2017). Yet the southern states were also outstripped in turn in both absolute and per-capita terms by the industrialising North, 
where at least 14,194 companies were incorporated during the same period (Davis, 1965, vol. ii, 24-9; Wright, 2014, pp. 58-60; Wright, 2009; Wright, 2011). Since the main difference between these two regions was that of slavery, Wright thus concludes that, whatever the profits accruing to individual planters, slavery as a whole was a negative externality for the wider regional economy, '[so] the pollution that spewed forth from the slave system, much like its effect on the overall economy, stunted the growth of corporate entrepreneurship but did not completely stifle it' (Wright, 2011, p. 208).

A focus on regional and national incorporation patterns of incorporation can therefore help to reassess recent work by Sven Beckert, Seth Rockman and others on the close interdependence of American capitalism and slavery, and show that the impact of slavery on economic development was not 'at once self-evidently true and empirically obscure', as they have claimed (Beckert and Rockman, 2016, pp. 1, 6, and, more broadly, Beckert, 2014; Beckert and Rockman, 2016). Largely restating the thesis first put forward by Eric Williams in 1944, that the profits and products of Caribbean slavery helped to support industrialisation in the British Isles after 1800 at the expense of the economies of the West Indies (Beckert and Rockman, 2016, p. 6; Williams, 1964; Solow and Engerman, 1987; Inikori, 2002; Ashworth, 2017), both approaches draw a direct link between slavery on the one hand and industrial development on the other, and overlap with recent work on the rise and fall of the 'second slavery' in Cuba and Brazil in the nineteenth century (Beckert and Rockman, 2016, p. 11-12; Tomich (ed.), 2017; Rood, 2017; Kaye, 2009). Yet the empirical basis for some of these claims has been strongly contested, and it is also increasingly clear that the impact of the economic developed fuelled by slavery on an industrial scale was at best uneven 
(Olmstead and Rhode, 2018). Slavery in the nineteenth century facilitated a range of important economic changes, particularly the expansion of cotton textile manufacture on an industrial scale in the British Isles and the north-eastern United States, yet Wright's figures for company formation suggest that it could also have a negative impact upon economic development within the territories where it existed. In the case of Jamaica, the gross domestic product of the island may have halved between 1800 and 1850 , a trajectory which the relative absence of joint-stock corporations that were able to mobilise and deploy capital, technology and managerial expertise may have both reflected and exacerbated (Graham, 2017, p. 199; Eisner, 1961, pp. 43-6). A comparative study of levels of incorporation between the British West Indies and the American South, like Wright's comparison of regional rates of incorporation within the United States itself, therefore provides a useful yardstick for judging the impact of slavery upon the economies of these regions and assessing what lay behind this

In particular, a close study of incorporation in the British West Indies between 1790 and 1860 suggests the damaging impact which slavery could have on the formation of new companies, which denied the islands - and, to a lesser extent, the American South - many of the benefits enjoyed elsewhere. In 1790 there were no corporations active in the region. The colonising companies of the seventeenth century were defunct, as were the Royal African Company and the South Sea Company, the two multinationals chartered by the British government in 1672 and 1711 with monopolies to manage the trade between West Africa and the Americas in enslaved people and goods respectively (Mancke 2005; Carlos and Nicholas 1996; Jones and Ville 1996). Even as incorporations rose in Britain and the United States after 1790, only about thirty companies were chartered by colonial assemblies before 1860 , excluding the various 
colonial acts giving legal recognition to imperial companies such as the Colonial Bank, a multinational bank founded by royal charter in Britain in 1836 (Baster, 1929: 67-77). About twenty other companies proposing to operate in the West Indies were also established in Britain after 1844 under the authority of the Board of Trade, and a small handful were incorporated by parliamentary statute or royal charter, such as the Colonial Bank (Table 1). An unknown number of corporations were also established in Britain and the West Indies as unincorporated co-partnerships - such as the West India Land Investment Company, founded under a deed of settlement by radical philanthropists in 1839 to buy up bankrupt plantations for resale to former slaves but since there is no way systematically to recover their numbers, and as they are not counted in Sylla and Wright's figures, they are not included here. (Harris, 2000, pp. 28-32, 137-67; Hannah, 2014, pp. 868-71; 'Deed', 1839).

\section{[Insert Table 1 here]}

By any criteria these were miniscule numbers. During this time the population of the British West Indies rose from about 800,000 to 1.1 million, so the total level of incorporation in and for the region therefore rose from virtually nothing before 1831 to a miserly peak of 3.0 companies per 100,000 people in the 1850 s (Table 2). By contrast, the American South was already oustripping the West Indies in the 1790s, and over 3,500 companies or about 32.7 per 100,000 people were founded in the 1850s (Wright, 2011, p. 212). The nominal capital of these companies was about $\$ 1.8$ billion in total, or between $\$ 60$ and $\$ 100$ per head between 1831 and 1860 , whereas both colonial and imperial incorporations in and for the British West Indies probably did not exceed $\$ 68$ million during the same period, or about $\$ 1.7$ to $\$ 2.9$ per head. 
Over two-thirds came from Britain. Predictably, the companies incorporated in Britain tended to have a larger nominal capital, about $\$ 1.4$ million on average, and even colonial companies had an average capital of $\$ 0.63$ million in this period, compared to $\$ 0.25$ million in the American South (Table 2). This reflected the fact that incorporation in and for the British West Indies was dominated by ventures for finance, transportation and mining, which tended to benefit most from larger capitals (Hall, 1959, pp. 152-3, 224; Eisner, 1961, pp. 180, 196-7; Callender, 1965, pp. 5-13; Lobdell, 1972, pp. 37-8; Green, 1976, pp. 214-18; Butler, 1995, pp. 131-9). Only a few agro-industrial businesses were set up, with serious long-term consequences which will be discussed on more detail below. Slavery therefore seems to have had a direct and visible impact on the levels of company formation and thus capital aggregation and investment. Companies were much more likely to be founded in the northern United States than in the South, where slavery was prevalent, but it is now clear that they were still more likely to be founded in the South than in the British West Indies, where slavery was even more prevalent and where it exercised a far greater influence on society and economy.

\section{[Insert Table 2 here]}

However, a large body of work now shows that planters in the West Indies eagerly adopted new technologies and working practices and invested large sums in improving the management of their estates during the eighteenth and nineteenth centuries, responding to opportunities for profit created by local and global markets (Gudmestad, 2006, pp. 380-1; Tomich, 1990; Follett, 2005; Roberts, 2013; Burnard, 2015, Burnard and Garrigus, 2016; Zahedieh, 2013; Rood, 2017; Rosenthal, 2018 ). 
The question then is why planters in societies and economies such as Jamaica did not therefore employ the important managerial and financial technology of the chartered company to the same extent as their counterparts in the American South, let alone in Britain or New England, despite similar economic challenges and social conditions within the plantation regions, and common political and legal institutions. The chance survival of a small series of papers relating to the Close Harbour Company of 1795 , assembled in 1802 to persuade the governor of Jamaica to agree to new legislation, can help to rule out certain factors. The promoters addressed and overcame many of the same objections that joint-stock companies faced elsewhere, and although the process of forming the company in Jamaica was not without its setbacks, these reflected serious problems in finance and management familiar to other joint-stock companies in the British Isles and the United States rather than anything specific to Jamaica. The reasons behind these lower levels of incorporation in the British West Indies were therefore neither political or legal, since islands such as Jamaica inherited the same constitutional framework as other colonies and former colonies in North America. Instead, the cultural, social and economic elements which made these islands so distinct compared even to the American South - the overriding importance of plantation slavery - may have reduced the potential for widespread incorporation, which affected in turn subsequent efforts to capitalise on new industrial technologies and processes. Slavery thus may have benefitted industrialising regions such as Britain and even individual planters and capitalists in the Caribbean, but the patterns of incorporation in places such as Jamaica show that it could also actively undermining the spread of capitalism and economic development in these places. 
The formation of the Close Harbour Company in 1795 was driven by urgent necessity. The production of sugar, rum, coffee and other tropical produce had risen continually in the eighteenth century, particularly after the Haitian Revolution of 1791 and the outbreak of war in 1793 ruined the sugar industry on foreign islands in the West Indies (Drescher, 1977; Ryden, 2009). Shipments of sugar alone from Jamaica tripled from 34,000 tons in 1783 to nearly 100,000 tons in 1805 , while the island also increased its exports of coffee and other products, and its imports of provisions, timber, manufactures and enslaved people rose in due proportion. The gross domestic product of the island may have doubled or even tripled between 1750 and 1800 (Graham, 2017, p. 199). This economic boom placed unprecedented pressure on the maritime infrastructure of the island as shipping traffic increased from just under 60,000 tons in 1772 to 85,000 tons in 1787 , and averaged about 150,000 tons per year in the 1790s and 190,000 tons in the 1800s (Long, 1774, vol. i, 504; Edwards, 17931801, vol. i, 284-5; JHA, 1812-26, vol. x, 437, vol. xi, 118, 195, 341, 500, 595). The rise in shipping reflected not just the rise in overseas trade but also the poor condition of roads within the island, which made planters reliant on coastal shipping (Maunder, 1954, pp. 161-5; Eisner, 1961, pp. 177-81). Port facilities throughout Jamaica came under great pressure and the ability of the island to benefit from this boom would thus depend on its capacity to manage shipping more efficiently. As Jackson noted of outports in the British Isles, 'both large and small were indispensable so long as coastal shipping remained cost effective ... small ports were a crucial part of economic development, even if they were not directly involved in overseas trade' (Jackson, 2001, p. 17). Planters in Jamaica and elsewhere had already spent large sums on building roads, bridges and other public works to address such problems, not 
least the construction of a major breakwater or 'molehead' at Bridgetown in Barbados after 1772 , but these had always been done by legislative, municipal or parochial committees or private individuals (Spurdle, 1962, pp. 94-110, 127-46, 166-79). The Close Harbour Company was an institutional innovation that was intended to address these problems by increasing capacity at Montego Bay.

This in itself was not a cause for contention, because the deficiencies of the harbour at Montego Bay had been recognised for some time. When the Jamaican historian and planter Edward Long made a comprehensive and systematic survey of the island in 1774 he identified only four key ports, besides the superb natural harbour at Kingston: those at Port Antonio, Lucea, Savanna-la-Mar and Montego Bay (Long, 1774, vol. ii, 41-2, 46, 69-70, 74-6, 79-81, 155, 157-8, 170-3, 176, 185-7, 192-3, 200-3, 207-9, 221; Higman, 1991; Hunt, 2010). The latter was the most important of the four, and had become 'the emporium of the western part of the island' and flourished as merchants and artisans settled there and made it the entrepôt of western Jamaica (Long, 1774, vol. ii, 200-1, 212-16; Hunt, 2010, pp. 490, 492-3). However, Long warned that the harbour and shipping were also exposed to gales in winter, and a survey for the British Admiralty in 1791 confirmed that these 'often damage or drive some of the shipping on shore' (Long, 1774, vol. ii, 213, 215-16; Leard, 1792, pp. 39-40). Drawn up in the same year, the map in Figure 1 shows that there was no protection for ships exposed to these winds. At least 100 vessels were lost this way between 1774 and 1794 , including 24 during a hurricane in October 1793 which had at last convinced local merchants and planters that something had to be done. The town had canvassed for help in the past and had even lobbied the marine insurers in London, '[but] it was not till the town had arrived at its present magnitude and immediately after an event as 
melancholy and fatal [as the hurricane of 1793] ... that the project could be brought forward with any probable means of success' ('Observations', 1802, ff. 1-2). Improving the harbour at Montego Bay would allow increased traffic and lower the cost of shipping and insurance to planters, enabling them to sell their sugar more cheaply, and also fend off competition from the town of Falmouth just 20 miles to the east, which had a far better anchorage and was investing in new wharves and quays (Ogilvie, 1954, pp. 12-15, 32-43; Higman, 1991, pp. 120-8; Besson, 2002, pp. 54-80).

\section{[Insert Figure 1: Montego Bay (1791)]}

Planters and merchants in Montego Bay therefore decided to incorporate by special legislative enactment of the assembly a joint-stock company, with a capital of some $£ 20,000$ and limited liability for its shareholders, for the construction of an enclosed or 'close' harbour in the north-stern part of the harbour in a small cove known as Meagre Bay. As shown in Figure 2, two large breakwaters or piers (marked 'd') would be laid out, about three hundred yards long and forty foot deep, to enclose an area (marked 'c') some four hundred yards square. Unlike the West India Docks in London it would not be provided with quays, wharves and warehouses for storing and transferring cargoes, though it was hoped that once it had been completed private individuals could be induced to erect them ('Observations', 1802, f. viii). It was instead intended primarily as a harbour of refuge, to shelter shipping during the worst storms and helped to reduce the cost of insurance and freight ('Observations', 1802, ff. iii-vi; Matkin, 1976; Swann, 1960, p. 37). The nature of the resistance that the new joint-stock company faced can be gauged from a manuscript pamphlet from 1794, entitled Observations on the Origin and Progress of the Plan for making Meagre Bay 
a Close Harbour and added to the bundle of materials assembled by the company in 1802 ('Observations', 1802). Clearly intended for wider circulation, either in manuscript or as the basis for a printed circular, the pamphlet was written to answer the objections that the company though it might encounter, and therefore provides a unique insight into these objections and the answers that the company offered.

\section{[Insert Figure 2: Montego Bay (1808)]}

'It is novel', the anonymous author admitted at the start of his pamphlet, 'for a number of private individuals in the West Indies to undertake an object of public utility of so great a magnitude', and he likewise conceded that there were 'so many circumstances to deter men in this country from engaging in them and to repress public spirit, that the merit can hardly be allowed as possible.' In affairs of such a novel nature, explanations were necessary, since it was impossible to blame men for opposing even such reasonable proposition if they were not presented to them in a clear, candid fashion. 'To remove such fears or jealousies, and to give the necessary information to form a proper judgement on the subject', he noted, 'is the object of the following pages'. His central argument was that the Close Harbour Company was necessary. 'The object of the bill is one of great public interest, as much so as any object of general government', he stated, but also one of considerable expense and risk. 'Under these disadvantages, individuals come forward and offer to execute it, notwithstanding its risk, and notwithstanding the doubt of the profits, provided their property is secured', he concluded, 'provided duties are laid for their reimbursement, and which duties are far beneath the advantages to be reaped by the individual who 
pays them', who would then have the protection of the close harbour. Three points were offered to justify granting the privilege of incorporation to the venture.

The first point was that the cash for building the harbour could only be raised by a joint-stock company. At a time when the annual revenue of the parish of St James, where Montego Bay was located, did not exceed $£ 10,000$ per year, the author of the Observations estimated that it would cost twice that merely to build the breakwaters, and a further sum each year to maintain them, to repair the anchors and chains used to secure ships during storms, to dredge the harbour, and pay the staff and enslaved people employed. 'The sum was too considerable to expect the legislature would appropriate it to produce an advantage, however great, to any single parish', and it exceeded the means of any individual planter or merchant, making it very unlikely that it would be built as a private venture. The second point was that if the funds were raised by voluntary subscription, the investors needed to be confident that their investment was secure. Fears might be entertained, noted the author, 'lest the necessary precautions may be wanting, to secure to the individual the return he seeks when he advances his property to produce a public benefit and consigns the management of it to a company'. To this end, the act of incorporation would include measures to protect investors by permitting the company to build up a reserve fund for dividends and contingencies; by prescribing measures for winding it up and returning the individual shares; and by allowing the company to borrow a further $£ 10,000$ at six per cent interest if necessary rather than issue more shares. Together with the standard measures giving shareholders the power to elect directors and hold them to account at annual and special general meetings, or to sell and dispose of their shares at will, this was intended entirely to defuse all fears in Jamaica about the potential for the abuse of 
corporate power at the expense of the shareholders (Seavoy, 1982; Harris, 2000; Freeman, Pearson and Taylor, 2013; Wright, 2014, pp. 9-48, 116-91).

Thirdly and most controversially, the author proposed that the company would not only raise at least $£ 20,000$ in share capital but also collect a general duty from all the shipping entering Montego Bay, even if they did not use the close harbour, as was the case in similar harbours such as Ramsgate in Britain (Matkin, 1976, p. 68). He was aware that some might worry that the company would merely becoming a corporation of rent-seekers, like many other chartered companies with monopoly powers in the seventeenth century noted above. 'Chartered rights also are novel here', he admitted, 'and in consequence, fears might be entertained lest ... the public may not derive those advantages from them which are the motives for giving exclusive privileges to a company of individuals', so he assured readers that its demands were fair and that the privileges would not be abused. 'It is just for all vessels coming to Montego Bay to pay the duty, because on any appearance of danger they can make use of it', he argued, but he recognised the possibility of resentment and stated that the company would only collect the duties once the work on the breakwaters was underway, 'to conciliate the public mind to a novel though necessary undertaking'. The examples of Ramsgate and other harbours were used as precedents. Though the founders also proposed to secure an exclusive jurisdiction over the harbour, with the power to make and enforce its own bye-laws, the author argued that the powers, 'such as they are', were limited only to the harbour itself. Further clauses would give the company the power to regulate shipping and to prevent damage to the breakwaters by fines and penalties, and would require ships using Montego Bay to dump their ballast next to the piers to save money on materials. '[But] this is a common provision of similar 
laws', noted the author, who once again provided English precedents for all of these measures. The main thrust of the Observations was therefore to address relatively familiar and predictable concerns about chartered companies and the potential abuse of privileges which were being debated in Britain and the United States at the same time, and to find precedents which justified the measures they had decided to adopt.

-III-

This approach then carried over into the actual chartering of the company, by an act of the assembly in 1795 which borrowed directly and openly from British precedents, and enabled the company painlessly to overcome all the objections which the author of the Observations had anticipated. Once the decision had been made in October 1794 by the supporters to apply for a bill, a meeting was advertised and a draft of the petition that would be presented to the assembly for the company was left open for popular inspection in the Post Office at Montego Bay ('Observations', 1802, f. i; JHA, 1812-26, vol. ix, 299). It was then laid before the house in November on behalf of the projectors by one of the members of assembly for the parish of St James, who also sat on the committee that then drew up the bill (JHA, 1812-26, vol. ix, 299, 331, 338, 342, 352). 'The notes of the clauses, as soon as formed, were sent to Montego Bay for the consideration of the inhabitants and to gain their observations, which were then incorporated into the body of the bill', according to the Observations, testifying to an ongoing dialogue between the assembly and interest groups in Montego Bay, who left the final draft of the bill open for inspection for several days before it was approved and returned to the committee of house of assembly to be passed into law ('Observations', 1802, ff. ii-iii). Several further amendments were then made by the 
house but the bill eventually became law on 28 February 1795, and directors were duly elected from amongst the leading planters and merchants in Montego Bay and the surrounding area, the social and economic elite of the island (Almanac, 1799, 1808; Petley 2009; Ryden 2009). No legal obstacles blocked the wider incorporation of companies in Jamaica, therefore, and a study of why the Close Harbour Company failed to fulfil its ambitions likewise shows that the problem was not the resistance offered by Jamaican society but the inherent defects of the project and its managers, most of whom lacked expertise and experience in large infrastructure projects and proved unequal to its financial, technical and managerial demands.

The provisions of the act itself can be divided into three main groups, each tied to the main purpose expressed in its preamble, '[to] make a safe close harbour, by means of piers, moles and banks ... thereby affording shelter and security for the shipping therein' (Laws, 1812-26, vol. iii, 81-100). It was based heavily on comparable English acts, particularly the statutes creating harbours of refuge in Scarborough in 1732 and Ramsgate in 1753, and the author of the Observations noted that its length it had over fifty clauses - 'is owing to the inconveniences that have been found in England where such regulations were not inserted originally in the body of similar laws, and the consequent necessity of applying to Parliament for additional powers and regulations' ('Observations', 1802, f. viii). The first group of provisions formed the subscribers into a corporate body and fixed its capital at $£ 20,000$; regulated how the shares were to be issued and traded; and established the procedures for corporate governance, all of which were modelled fairly closely on similar procedures in Britain and North America. The second group gave the company's directors the powers to appoint officials and contractors to build and maintain the moles. The third group 
regulated shipping and the use of the harbour, setting the tariffs noted above and penalising masters who dumped ballast or otherwise damaged the harbour. To English precedents were added elements specific to the needs of a slave society, such as clause 28 , which required that 'every ship or vessel lying or being in the close harbour shall always have a fit and proper white person on board, to take charge of such ship or vessel', reflecting an unwillingness to allow enslaved or free people of colour any responsibility or opportunities that might threaten white rule. The act thus offered most of the powers necessary for the directors of the company to meet their ambitions, based on the proposals put forward earlier in the Observations.

The difficulty that the company faced was mainly to translate these ambitions into reality by overcoming major legal, financial and engineering problems which the directors, who were mainly planters and merchants rather than engineers, lacked the experience to anticipate and the expertise to avoid. The legislation itself was found to be inadequate. 'Notwithstanding the great pains in the preparation of this bill, it remains for experience to put it to the test', the Observations noted, adding that 'imperfections no doubt will be found in it, and the liberality, justice and wisdom of the legislature will correct them' ('Observations', 1802, f. viii). But at least two supplementary acts were required. In 1799 the company asked the assembly for an amendment that would double harbour duties and remove the original deadline, since delays in building the harbour had led to acute financial shortfalls' ('Deficiencies, 1802). Surveying had begun early in 1795 but had been overtaken by the Second Maroon War in July, which saw extensive fighting with communities of black runaways or 'maroons' in the hills above Montego Bay (Craton, 1982, pp. 211-23). Though the war did not touch the town directly it led to shortages of materials and 
labour, which, the company claimed in 1799, 'has subjected them to very heavy [and] extraordinary expenses in the procuring of labour, both of superintendents and negroes, [and] in the purchasing of flats, powder, blasting tools, mooring anchors, etc' (JHA, 1812-26, vol. $\mathrm{x}, 318$ ). More serious was falling out with their original contractor, who died before the harbour was completed. Between 1797 and 1802 the company spent nearly $£ 30,000$ on the harbour but received only $£ 8,500$ in tonnage and harbour duties, exhausting the first subscription of $£ 20,000$; as in many other companies, the directors underestimated the cost of construction and overestimated their revenues ('Accounts', 1802; JHA, 1812-26, vol. xi, 31).

The first amending act was duly passed but two years later the company once again laid its troubles before the assembly. It had been necessary to float another loan of $£ 10,000$ in May 1801 but only $£ 3,000$ had been subscribed by August, 'nor is more likely to be raised while public papers, agriculture and commerce offer monied men returns superior to the legal interest, unless the company is permitted to give a greater rate than six per cent', the maximum rate of interest permitted by the usury laws in Jamaica ('Observations', 1802; 'Deficiencies', 1802; JHA, 1812-26, vol. xi, 31). Experience had shown that the penalties that prevented ships from dumping ballast inside the harbour were still inadequate and the second amending act therefore raised them (Laws, 1802-24, vol. iv, 11-17, 255-6). Although the moles were largely complete by 1804 the process had therefore taken far longer than the company had expected, and they were forced to compromise on key elements. 'Folding gates were to have been placed at the mouth of the channel, after the fashion of English docks', noted the Falmouth Post in December 1846 '[and] the breakwater was to have been extend to the wharf called Gordin's, and the said breakwater was to have been several 
feet higher than it was built' (Falmouth Post, 1846). In October 1844 the moles were almost entirely destroyed by a severe storm which swept away most of the structures above the water and turned the rest into a navigational hazard. To justify their charter and address complaints that the company now existed only to collect rents and pay dividends to shareholders, the directors had to bring in three engineers from Scotland for repairs (Votes, 1847, pp. 175-6; Falmouth Post, 1847).

Reality therefore proved far more stubborn and intractable than the supporters of the close harbour company had hoped, and the venture never fulfilled their ambitious aims. In this it was hardly alone. Both the West India and Liverpool dock schemes successfully consolidated the position of London and Liverpool as leading mercantile centres, but the immense investment by the corporation of Bristol in its new docks did not prevent its trade and traffic flowing elsewhere (Williams, 1962, pp. 131-88). The town of Grimsby in north-eastern England invested at least $£ 70,000$ in a new dock between 1796 and 1798 that did not capture any passing trade and saddled the town with an unsustainable debt (Jackson, 1971, pp. 43-54; Ross, 2009). The problems facing the Close Harbour Company in Jamaica in 1795 were never successfully surmounted, but they were largely the same problems faced by other public infrastructure projects and joint-stock companies in Britain in this period and did not derive specifically from the particular conditions of slave societies in the British West Indies. The importance of the company for the wider history of slavery, capitalism and incorporation therefore lies not so much in why it failed, but in how it came to be chartered in the first place. As noted above, the Observations agreed that it was 'novel for a number of private individuals in the West Indies to undertake an object of public utility of so great a magnitude', but this novelty was not because Jamaica threw 
legal obstacles in the way of entrepreneurs. When the cause was good enough, as in 1795, ventures such as the Close Harbour Company could find legal and financial backing: '[we] put the inhabitants to the truest test of approbation men can give of any concern, that is, to call on them to subscribe towards its execution', boasted the Observations, and this test was met. It therefore must have been something integral to the nature of the slave society and plantation economy which caused lower levels of incorporation in Jamaica and other islands compared to other regions.

$-\mathrm{IV}-$

As noted above, the pioneering effort in Jamaica was not followed by a rush of similar incorporations. In nearby Falmouth local investors successfully lobbied the Jamaican assembly for a similar charter of incorporation in 1799 for the Falmouth Waterworks Company, a public works project to introduce piped water to the town, but no more joint stock companies were chartered in Jamaica or elsewhere until the 1820 s, and even then the level of incorporation remained far below that of the American South (Graham, 2018). Slavery itself therefore acted, as Wright has argued, as something of a brake upon incorporation and industrialisation, and with greater effect in the British West Indies than in the American South, because slavery dominated their economies and societies to a far greater extent. Having ruled out legal and political circumstances, more work is needed to establish what the exact links were between cause and effect, but a preliminary examination suggests that it may have been related both to exogenous economic factors, in particular the abolitionist and free trade policies imposed by the metropole in the early nineteenth century, and to various endogenous factors relating to the particular dominance of plantation slavery in the 
region. These factors made it difficult to mobilise local or metropolitan capital for the agro-industrial investment necessary to keep pace with competitors in Cuba and Brazil who still had the advantage of cheaper slave labour, leading to a spiral of noninvestment and economic deterioration and a much lower rate of incorporation, despite the example provided in Montego Bay.

The British West Indies suffered a long, albeit uneven, process of economic decline after 1815 (Hall, 1959, pp. 1-120; Eisner, 1961, pp. 189-202; Green, 1976, pp. 191 206; Bulmer-Thomas, 2013, pp. 78-160; Ryden, 2009). The end of the British slave trade in 1807 cut off supplies of cheap labour and, as the abolitionists had hoped, forced planters to spend more on the care of their slaves. The end of the Napoleonic war in 1815 led to the return of occupied foreign islands and the removal of commercial blockades, and enabled foreign sugar to reach Europe and undercut the sugar sold by British planters struggling with higher labour costs. These problems were increased after the imperial government banned slavery in 1833 and ended in 1838 the short period of 'apprenticeship' or indentured service intended to smooth the transition to free labour, as well as removing between 1846 and 1852 all tariff barriers in Britain against cheaper, slave-grown foreign sugar. Despite efforts to force exslaves back onto the plantations or to import indentured labour from South Asia, many planters were unable to compete and went bankrupt. 'Jamaica cannot hope to exist as a sugar colony in her present state: she is nearly bankrupt in everything essential to her welfare', one writer complained in 1847, vainly concluding that the answer was not economy and retrenchment but greater levels of investment: 'she requires capital to be expended in centralising her manufactories and providing tram roads for canes' (Jelly 1847, p. xiv). Even after the formation of several imperial and colonial banks 
in the 1830 s, planters in Jamaica complained continually about the shortages of capital which prevented them from making the necessary improvements to their estates (Hall, 1959, pp. 32, 121-3, 146, 153-5; Eisner, 1961, pp. 196-8, 305-8;

Callender, 1965, pp. 13-24; Lobdell, 1972, pp. 31-46). Similar complaints were heard in British Guiana, Trinidad and Barbados, even though planters had more success importing several waves of indentured labourers in order to keep wages low (Green, 1976, pp. 218-22; Moohr, 1972; Adamson, 1972, pp. 160-88; Brown, 1990).

Economic decline reduced the local capital available for investment, and discouraged British capitalists from putting their own money into the improvement of agriculture in these colonies.

By contrast, the American South enjoyed a period of economic growth from 1790 to 1860 based on slavery that created great confidence in its long-term economic future, and may have encouraged projectors to set up new companies and investors to back them. As Fogel has noted, despite short-lived depressions in the 1830s and 1840s, 'there was never a time between the American Revolution and the Civil War that slaveholders in the Old South became so pessimistic about the economic future of the peculiar institution [i.e. slavery] that their demand for slaves went into a period of sustained decline' (Fogel, 1989, p. 63). Investors were therefore still willing to put money into the economy of the American South, particularly the credit which was crucial for the industrialisation of the plantation system (Schermerhorn, 2015; Schweikart, 1987; Kilbourne, 2006). Significantly, incorporation in the British West Indies only revived in the 1830 s when the payment of $£ 20$ million in compensation to the former owners of enslaved people after 1834 released a tidal wave of liquidity which coincided with the banking boom in Britain and North America of the 1830s 
(Draper 2010). This made capital available for investment in new companies, though the total nominal capital of the companies founded in this decade was only a quarter of this, some $£ 5.4$ million or about $\$ 25$ million, and the actual paid up capital was probably significantly lower (Table 2). Further incorporations followed in subsequent decades as the capital generated by the 'railway mania' of the 1840 s and the mining boom of the 1850s supported companies chartered in Britain for operation in the West Indies, and spilled over into the region to support the establishment of several more chartered companies there. The incidence of incorporation and capital inflows probably had little to do with the colonial status of West India islands such as Jamaica, both because incorporations clearly followed these wider economic patterns and because at the same time British investors were also pouring large sums into other British territories such as India, Canada and Australia, as well as the United States and South America where Britain had no formal political power at all but maintained an 'informal empire' (Jenks 1971; Wilkins, 1989: 49-89; Thorner, 1950).

The West Indies therefore had a distinct pattern of incorporation between 1790 and 1860 because of exogenous developments in the world economy, particularly the competition from the 'second slavery' economies in Cuba and Brazil and the rise of remunerative investments for British capital elsewhere in the Americas and India, and because of a range of endogenous social and economic factors which prevented the extensive mobilisation of local capital by incorporation. Absenteeism was probably also of little importance, since it varied substantially across the British West Indies, and was often a conduit through which plantations could import British investment, technology and expertise (Higman, 2006; Burnard, 2004; Draper, 2012; Smith and Forster, 2013). More significant was probably the continued concentration of colonial 
wealth in a small planter class, greater in Jamaica in 1774 than the American South '[and] by far the highest inequality for any pre-industrial economy that can be documented' - may have helped to starve the economy of capital that would otherwise have been invested in companies (Burnard et al. 2019; Lindert and Williamson 2016; Eisner 1961: 321-4; Williams, 1964). The strict cultural and social barriers which were created to maintain the racial hierarchies inherent to the operation of slavery, and which persisted after 1834, ran contrary to the spirit of 'shareholder democracy' that has been detected in the joint-stock corporations of Britain and the United States, and may have discouraged entrepreneurs within the islands from founding companies that were open to widespread participation. The emphatic refusal of West India planters to invest money in public works at the expense of personal consumption was a refrain of imperial officials and commentators throughout the period, and has led historians to conclude that '[the] exaggerated individualism of the British West Indians asserted itself most markedly in their lack of cooperation in carrying out public enterprises' (Ragatz, 1928, pp. 10-11). In fact, as noted above, planters invested heavily during the eighteenth century in public works such as the Molehead at Barbados, but the widespread perception that this was exceptional - demonstrated by the rhetorical flourish in the Observations that such public works were 'novel' - may have served to dissuade entrepreneurs from proposing such schemes. Most or all of these factors lay more heavily on the American South than Britain or the rest of the United States, and even more heavily on the British West Indies than the American South, and may help to account for the significant differences in levels of incorporation which this study has demonstrated. 
Slavery therefore served to reduce rates of incorporation, and, by denying the British West Indies many of the benefits which incorporation offered, may have exacerbated in turn the speed of economic decline. Without turnpike, dock, harbour, railway and steam navigation companies such as the failed Jamaica Coast Steam Packet Company, which told the assembly of Jamaica in 1827 that it would be of benefit to the island but 'cannot be effected unless an enactment be passed constituting the subscribers into a company, so as to render each member responsible only for his individual share', the islands faced much higher transportation costs, which made their economies less competitive (Votes, 1827, p. 131). As a result, they were even less able to compete with planters in Cuba and Brazil to sell cheap sugar to Britain, and to get sufficient capital to reinvest in further incorporation or other industrial improvements. The low number of agro-industrial corporations founded in the British West Indies during this period is significant. In circumstances when major investors in Britain preferred to put their money into new plantations in Cuba and Brazil, such corporations offered a means for planters in Jamaica to raise capital and support the managerial skills needed to exploit modern technologies and thereby enjoy the benefits of economies of scale and overcome the problems of high labour costs (Galloway 1989: 120-94; CurryMachado 2011). For instance, in 1846 the promotor of the Jamaica Central Factory Company pointed out the many economic benefits of consolidating sugar manufacture into a central 'factory', for cheaper and more efficient milling, refining and distilling, and the secretary of the Royal Agricultural Society of Jamaica concluded that 'it is to central manufactories that we must look for the improved machinery and scientific processes which the individual cannot afford to adopt' (Fyfe, 1846, p. 37). It required though an investment of over $£ 100,000$, which had to come from a joint-stock company rather than the planters themselves, '[as] they have had neither the time, the 
means, the labour, nor perhaps the confidence of position requisite for carrying out improvements which involve a radical change from the system of management pursued by their predecessors' (Fyfe, 1846, pp. 15-16).

In this case the promotor of the Jamaica Central Factory Company managed to obtain an act of incorporation from the colonial assembly, though it was later disallowed by the imperial government. The act allowed the shareholders to raise up to $£ 300,000$ for 'the improvement of the manufacture and preparation of sugar ... promoted by the separation thereof from the practice of agriculture', and gave them limited liability and full powers to expropriate land for the construction of a tramway to transport cane (Acts, 1848, pp. 753-69). A prospectus was issued for another company in 1847, the Westmoreland Central Factory Company, which proposed to raise $£ 40,000$ under similar terms and to make available to local planters 'the facilities of an improved, expeditious mode of manufacture' that would bring several thousand acres of cane land into cultivation (Jelly, 1847, p. 56). 'Central factories are the talisman to disenthrall us from present perplexity and future ruin', it added, '[and] to teach us to be satisfied with farming, to subdivide labour and thus acquire increased knowledge, dexterity and confidence', but without the necessary act of incorporation the promotors were unable to put this into practice. These were, moreover, exceptions rather than the rule. Though promoters naturally tended to over-sell the benefits of centralisation, the absence of widespread incorporations in Jamaica and other islands prevented planters from even experimenting with the financial and managerial advantages that the central factory system promised, and it therefore spread vary slowly in these colonies compared to other islands in the (Hall, 1959, pp. 76-80, 8595, 129-37; Eisner, 1961, pp. 202-5; Galloway, 1989, pp. 139-67; Schnakenbourg, 
1984). The effect was therefore to hold back the economic growth of the British West Indies by choking off the capital they needed to avoid the spiral of economic decline which most of them experienced during the nineteenth century. As Wright has suggested, slavery was therefore a form of economic 'pollution' which stunted incorporation and industrialisation in the British West Indies, to a greater extent than territories such as Cuba, Brazil and the American South, where slavery was less prevalent and which were benefitting by the mid-nineteenth century from vast inflows of capital which allowed greater industrialisation of their plantation economies.

$-\mathrm{IV}-$

The level of incorporation of joint-stock companies or corporations, both in absolute terms and relative to population, were therefore far lower in the British West Indies between 1790 and 1860 than in the American South, despite having economic and social systems based to varying degrees on plantation slavery. The causes and consequences for this difference require further work, but close examination of the first ever joint-stock company chartered by a colonial legislature in Jamaica suggests that these causes were neither political or legal, since planters and merchants there were able to secure a charter with relatively little fuss when the economic case was compelling enough. Lower levels of incorporation may therefore have reflected both exogenous and endogenous economic and social factors, including the geography and population of the British West Indies, the wider economic situation, and the corrosive social and economic effects of widespread slavery, which left a very large segment of the population in the islands without the human or material resources to establish or invest in joint-stock companies or to attract capital from outside. The intersection of 
slavery and capitalism in this period was therefore uneven. While slavery may have provided the raw materials and capital which drove industrial capitalism in New England and the British Isles, and also strengthened the economy of the American South, in the British West Indies it seems to have exacerbated and accentuated existing structural weaknesses and generated long-lasting economic problems that persisted far beyond the mid-nineteenth century. 


\section{$\underline{\text { References }}$}

Abbott, Charles Cortez (1936). The rise of the business corporation. Ann Arbor: Edwards Bros.

‘Accounts' (1802). National Library of Jamaica (MS 166). Kingston, Jamaica.

Adamson, A.H.. (1972). Sugar without slaves: the political economy of British Guiana, 1838-1904. New Haven, CT: Yale University Press.

Armstrong, John and Bagwell, Philip (1983). 'Coastal shipping'. In Derek H. Aldcroft, M. J. Freeman, and Bill Albert (eds.). Transport in the industrial revolution, pp. 142-76. Manchester: Manchester University Press.

Ashworth, William J., (2017). The industrial revolution: the state, knowledge and global trade. London; Bloomsbury Academic.

Baster, Albert S.J. (1929). The Imperial Banks. London: P.S. King \& Son.

Beckert, Sven (2014). Empire of cotton: a global history. New York: Alfred A. Knopf.

Beckert, Sven and Rockman, Seth (2016). Slavery's capitalism: a new history of American economic development. Philadelphia, PA: University of Pennsylvania Press.

Besson, Jean (2002). Martha Brae's two histories: European expansion and Caribbean culture-building in Jamaica. Chapel Hill, NC: University of North Carolina Press.

Bogart, Dan (2014). 'The transportation revolution in industralising Britain'. In Roderick Floud, Jane Humphries, and Paul Johnson (eds.). The Cambridge Economic History of Modern Britain, volume 1: 1700-1870, pp. 368-90. Cambridge: Cambridge University Press. 
Brathwaite, Kamau, The Development of Creole Society in Jamaica, 1770-1820 (Oxford, 1971) xvi, 374 p.

Bridenbaugh, Carl (1971a). Cities in revolt: urban life in America, 1743-1776. Oxford: Oxford University Press.

--- (1971b). Cities in the wilderness: the first century of urban life in America, $1625-$ 1742. Oxford: Oxford University Press.

Broadbank, Joseph G. (1921). History of the Port of London, 2 vols.. London: Daniel O'Connor.

Brown, Deryk. (1990). 'The response of the banking sector to the general crisis: Trinidad, 1836-56', Journal of Caribbean History, 24, 28-64

Bulmer-Thomas, Victor. (2013). The economic history of the Caribbean since the Napoleonic Wars. Cambridge: Cambridge University Press.

Burnard, Trevor G. (2015). Planters, merchants, and slaves: plantation societies in British America, 1650 - 1820. Chicago, IL: University of Chicago Press.

Burnard, Trevor G. (2004). 'Passengers only: the extent and significance of absenteeism in eighteenth century Jamaica', Atlantic studies: global currents, $1(2) .178-95$

Burnard, Trevor G. and Garrigus, John (2016). The plantation machine: Atlantic capitalism in French Saint-Domingue and British Jamaica. Philadelphia, PA: University of Pennsylvania Press.

Burnard, Trevor G., Panza, Laura, and Williamson, Jeffrey G. (2019), 'Living costs, real incomes and inequality in colonial Jamaica', Explorations in Economic History, 71 (1). 55-71

Butler, Kathleen Mary (1995). The economics of emancipation: Jamaica \& Barbados, 1823-1843. Chapel Hill, NC: University of North Carolina Press. 
Callender, Charles V. (1965). 'The development of the capital market institutions of Jamaica', Social and Economic Studies, 14 (3). 1-174.

Carlos, Ann M. and Nicholas, Stephen (1996). 'Theory and History: SeventeenthCentury Joint-Stock Chartered Trading Companies', Journal of Economic History, 56. 916-24

Craton, Michael (1982). Testing the chains: resistance to slavery in the British West Indies. Ithaca, NY: Cornell University Press.

Curry-Machado, Jonathan (2011). Cuban Sugar Industry: Transnational Networks and Engineering Migrants in Mid-Nineteenth Century Cuba. New York, Palgrave Macmillan

Davis, Joseph Stancliffe (1965). Essays in the earlier history of American corporations, 4 vols. New York: Russell and Russell.

Deed of settlement of The West India Land Investment Company (1839). Hamilton College Library. (M562). Hamilton College, NY

'On the Deficiencies of the first and second laws, and reliefs proposed' [hereafter 'Deficiencies'] (1802). National Library of Jamaica (MS 166). Kingston, Jamaica.

Draper, Nicholas (2008). 'The City of London and slavery: evidence from the first dock companies, 1795-1800', Economic History Review, 61 (2). 432-66.

Draper, Nicholas (2010). The Price of Emancipation: Slave-Ownership, Compensation and British Society at the End of Slavery. Cambridge: Cambridge University Press

Draper, Nicholas (2012). 'The rise of a new planter class? Some countercurrents from British Guiana and Trinidad, 1807-33', Atlantic Studies: global currents, 9 (1). 65-83 
Drescher, Seymour (1977). Econocide: British slavery in the era of abolition. Pittsburgh, PA: University of Pittsburgh Press.

Dubois, Armand Budington (1938). The English business company after the Bubble Act 1720-1800. New York: Commonwealth Fund.

Edwards, Bryan (1793-1801). The history, civil and commercial, of the British colonies in the West Indies, 3 vols. London.

Eisner, Gisela (1961). Jamaica, 1830-1930: a study in economic growth. Manchester: Manchester University Press.

Erikson, Emily and Bearman, Peter (2006). 'Malfeasance and the Foundations for Global Trade: The Structure of English Trade in the East Indies, 1601-1833', American Journal of Sociology, 112. 195-230

Falmouth Post (1846, December 5). The Montego Bay Close Harbour Company. Falmouth Post, xii, 5.

Falmouth Post (1847, October 26). The Close Harbour at Montego Bay. Falmouth Post, xiii, 43.

Fogel, Robert. (1989). Without consent or contract: the rise and fall of American slavery. New York: W.W. Norton.

Follett, Richard J. (2005). The sugar masters: planters and slaves in Louisiana's cane world, 1820-1860. Baton Rouge: Louisiana State University Press.

Freeman, M. J. (1983). 'Introduction'. In Derek H. Aldcroft, M. J. Freeman, and Bill Albert (eds.). Transport in the industrial revolution, pp. 1-30. Manchester: Manchester University Press.

Freeman, Mark, Pearson, Robin, and Taylor, James (2013). Shareholder democracies?: corporate governance in Britain and Ireland before 1850. Chicago: University of Chicago Press. 
Fyfe, Alexander Gordon (1846). Suggestions for separating the culture of sugar from the process of manufacture; with a plan for establishing a central sugar factory at Annotto Bay, Jamaica. London: Effingham Wilson.

Galloway, J.H. (1989) The sugar cane industry: an historical geography from its origins to 1914. Cambridge: Cambridge University Press.

Graham, Aaron (2018). 'Technology, slavery and the Falmouth Water Company of Jamaica, 1799-1805', Slavery \& Abolition, 39. 315-32.

Green, William A. (1976). British slave emancipation: the sugar colonies and the great experiment, 1830-1865. Oxford: Clarendon Press.

Gudmestad, Robert (2006). 'Technology and the world the slaves made', History Compass, 4 (2). 373-83.

Hall, Douglas (1959). Free Jamaica 1838-1865: an economic history. New Haven, CT: Yale University Press.

Hannah, Les (2014). 'Corporations in the US and Europe, 1790-1860', Business History, 56 (6). 865-89.

Harris, Ron (2000). Industrializing English law: entrepreneurship and business organization, 1720-1844. Cambridge: Cambridge University Press.

Higman, B. W. (1991). 'Jamaica port towns in the early nineteenth century'. In F.W. Knight and P.K. Liss (eds.). Atlantic Port Cities: economy, culture and society in the Atlantic world, 1650-1850, pp. 117-48. Knoxville: University of Tennessee Press.

Higman, B. W., et al. (1998). Montpelier, Jamaica: a plantation community in slavery and freedom, 1739-1912. Bridgetown, Barbados: University of the West Indies Press. 
Higman, B.W. (1976). Slave population and economy in Jamaica, 1807-1834. Cambridge: Cambridge University Press.

Higman, B.W. (2006). Plantation Jamaica, 1750-1850: capital and control in a colonial economy. Kingston, Jamaica: University of the West Indies Press.

Hunt, Carleton Bishop (1969). The development of the business corporation in England 1800-1867. New York: Russell \& Russell.

Hunt, Nadine (2010). 'Expanding the frontiers of western Jamaica through minor Atlantic ports in the eighteenth century', Canadian Journal of History, 45 (3). 485-502.

Inikori, J. E. (2002). Africans and the industrial revolution in England: a study in international trade and economic development. Cambridge: Cambridge University Press.

Jackson, Gordon (1971). Grimsby and the Haven Company, 1796-1846. Grimsby: Grimsby Public Libraries.

--- (1972). Hull in the eighteenth century: a study in economic and social history. London: University of Hull by Oxford University Press.

--- (1983). 'The ports'. In Derek H. Aldcroft, M. J. Freeman, and Bill Albert (eds.). Transport in the industrial revolution, pp. 177-208. Manchester: Manchester University Press.

--- (2001). 'The significance of unimportant ports', International Journal of Maritime History, xiii (2). 1-17.

Jelly, Thomas (1847), A brief enquiry into the condition of Jamaica; with a view to ascertain what steps might be taken to relieve that island from her perilous state of political and agricultural embarrassment. London: Pelham Richardson. 
Jenks, Leland Hamilton (1971), The Migration of British Capital, to 1875. London: Thomas Nelson and Sons.

Jones, Stephen and Ville, Simon (1996). 'Efficient Transactors or Rent-Seeking Monopolists? The Rationale for Early Chartered Trading Companies', Journal of Economic History, 56. 898-915

Journals of the House of Assembly of Jamaica (1812-26) (14 vols). Kingston, Jamaica; Alexander Aikman.

Kaye, Anthony E. (2009). 'The second slavery: modernity in the nineteenth-century South and the Atlantic world', The Journal of Southern History, 75 (3). 627-50 Kenwood, A.G. (1971). 'Capital investment in docks, harbours, and river improvements in north-eastern England, 1825-1850', The Journal of Transport History, 1 (2). 69-84.

Kilbourne, Richard. (2006). Slave agriculture and financial marekts: the Bank of the United States in Mississippi, 1831-1852. London: Pickering \& Chatto.

Laws of Jamaica (1802-24) (7 vols). Kingston, Jamaica; Aikman

The Laws of Jamaica, passed in the twelfth year of the reign of Queen Victoria (1849). Spanish Town, Jamaica: William J. Pearson.

Larson, John Lauritz (2001). Internal improvement: national public works and the promise of popular government in the early United States. Chapel Hill, NC: University of North Carolina Press.

Leard, John (1792). Sailing directions for the island of Jamaica and St. Domingue, or Hispaniola, and the windward passages. London: Printed for the author, by Daniel Bond.

Lindert, Peter H. and Williamson, Jeffrey G. (2016). Unequal Gains: American Growth and Inequality since 1700. Princeton, NJ: Princeton University Press. 
Lobdell, Richard (1972). 'Patterns of investment and sources of credit in the British West Indian sugar industry, 1838-97', Journal of Caribbean History, 4, 31-53. Long, Edward (1774). The History of Jamaica, or, General survey of the antient and modern state of that island, 3 vols. London: Printed for T. Lowndes.

Mancke, Elizabeth (2005). 'Chartered Enterprises and the Evolution of the British Atlantic World', in Elizabeth Mancke and Carole Shammas (eds.), The Creation of the British Atlantic World. Baltimore, MD: Johns Hopkins Univeristy Press. 237-62

Matkin, Robert B. (1976). 'The construction of Ramsgate Harbour', Transactions of the Newcomen Society, 48 (1). 53-72.

Maunder, W. F. (1954). 'Notes on the development of internal transport in Jamaica', Social and Economic Studies, 3 (2). 161-85.

Moohr, Michael. (1972). 'The economic impact of slave emancipation in British Guiana, 1832-1852', Economic History Review, 25, 588-607.

Nelson, Louis P. (2016). Architecture and empire in Jamaica. New Haven, CN: Yale University Press.

The New Jamaica Almanac and Register (1799). Kingston, Jamaica: Stevenson \& Aikman.

The New Jamaica Almanac and Register (1808). Kingston, Jamaica: Stevenson \& Aikman.

'Observations on the origin and progress of the plan for making Meagre Bay a close harbour' [hereafter 'Observations'] (1802). National Library of Jamaica (MS 166). Kingston, Jamaica.

Ogilvie, Dan (1954). History of the parish of Trelawny (Kingston, Jamaica: privately printed). 
Petley, Christer (2009). Slaveholders in Jamaica: Colonial Society and Culture During the Era of Abolition. London: Pickering \& Chatto.

Pettigrew, William (2013). Freedom's debt: the Royal African Company and the politics of the Atlantic slave trade, 1672-1752. Chapel Hill, NC: University of North Carolina Press for the Omohundro Institute of Early American History and Culture.

Ragatz, Lowell (1928). The fall of the planter class in the British Caribbean, 17631833: a study in social and economic history. New York: The Century Co.

Roberts, Justin (2013). Slavery and the Enlightenment in the British Atlantic, 17501807. Cambridge: Cambridge University Press.

Robinson, Ross (2009). 'The finances and fortunes of Yorkshire coast harbours in the nineteenth century', Northern History, 46 (1). 75-91.

Rood, Daniel (2017). The reinvention of Atlantic slavery: technology, labour, race and capitalism in the Greater Caribbean. New York: Oxford University Press, 2017.

Rosenthal, Caitlin (2018). Accounting for slavery: masters and management. Cambridge, MA: Harvard University Press.

Ryden, David (2009). West Indian slavery and British abolition, 1783-1807. Cambridge: Cambridge University Press.

Satchell, Veront and Sampson, Cezley (2003). 'The rise and fall of railways in Jamaica, 1845-1975', The Journal of Transport History, 24 (1). 1-21.

Scott, William Robert (1951). The constitution and finance of English, Scottish and Irish joint-stock companies to 1720, 3 vols. New York: Peter Smith.

Schermerhorn, Calvin. (2015). The Business of Slavery and the Rise of American Capitalism, 1815-1860. New Haven, CT: Yale University Press. 
Schnakenbourg, Christian (1984). From sugar estate to central factory: the Industrial Revolution in the Caribbean (1840-1905). In Bill Albert and Adrian Graves (eds.). Crisis and change in the international sugar economy 1860-1914 (pp. 83-94). Norwich, ISC Press.

Schweikart, Larry. (1987). Banking in the American South from the Age of Jackson to Reconstruction. Baton Rouge: Louisiana State University Press.

Seavoy, Ronald E. (1982). The origins of the American business corporation, 17841855: broadening the concept of public service during industrialization. Westport, CN: Greenwood Press.

Sheridan, Richard B. (1974). Sugar and slavery: an economic history of the British West Indies, 1623-1775. Barbados: Caribbean University Press.

Smith, S.D. and Forster, Martin, “The curse of the Caribbean'? Agency’s impact on the efficiency of sugar estates in St Vincent and the Grenadines, 1814-29', Journal of Economic History, 78 (2). 472-99

Spurdle, Frederick G. (1962). Early West Indian government: showing the progress of government in Barbados, Jamaica and the Leeward Islands, 1660-1783 .Palmerston North, New Zealand: published by the author.

Stern, W.M. (1952). 'The first London dock boom and the growth of the West India docks', Economica, 19. 59-77.

Swann, D. (1960). 'The pace and progress of port investment in England, 1660-1830', Bulletin of Economic Research, 12 (1). 32-44.

Sylla, Richard and Wright, Robert E. (2013). 'Corporation formation in the antebellum United States in comparative context', Business History, 55 (4). 650-66. 
Taylor, George Rogers (1951). The transportation revolution, 1815-1860. New York: Rinehart.

Thorner, Daniel (1950). Investment in empire: British railway and steam shipping enterprise in India, 1825-1849. Pennsylvania, PA: University of Pennsylvania Press

Tomich, Dale W. (1990). Slavery in the circuit of sugar: Martinique and the world economy, 1830-1848. Baltimore, MD: Johns Hopkins University Press.

--- (ed.) (2017), Slavery and historical capitalism during the nineteenth century. Lanham, MD: Lexington Books.

Votes of the House of Assembly of Jamaica (1827). The National Archives of the United Kingdom. (CO 140/115). London, UK.

Votes of the House of Assembly of Jamaica (1847). The National Archives of the United Kingdom. (CO 140/146). London, UK.

Williams, Alan F. (1962). 'Bristol Port plans and improvement schemes', Transactions of the Bristol and Gloucestershire Archaeological Society, 81, $131-88$.

Williams, Eric (1964). Capitalism \& slavery. London: Deutsch.

Wilkins, Mira (1989). The history of foreign investment in the United States to 1914. Cambridge, MA: Harvard University Press.

Wright, Robert, E.-- (2009). 'Corporations and the economic growth and development of the antebellum Ohio River valley', Ohio Valley History, 9 (4). 48-70.

--- (2011). 'Corporate entrepreneurship in the antebellum South'. In Susanna Delfino, Michele Gillespie, and Louis M. Kyriakoudes (eds.). Southern society and its 
transformations, 1790-1860, pp. 197-216. Columbia, MO: University of Missouri Press.

--- (2014). Corporation nation. Philadelphia, PN: University of Pennsylvania Press.

--- (2017). The poverty of slavery: how unfree labour pollutes the economy. London; Palgrave Macmillan.

Zahedieh, Nuala (2012). 'Colonies, copper and the market for inventive activity in England and Wales, 1680-1830', Economic History Review, 66 (3). 805-25 